13. "Kadaliosaums priscus, Credner, a new Reptile from the Lower Permian of Saxony": Amer. Journ. Sci., vol. xxxviii (1889), pp. 156-158.

14. "On the Classification of the Testudinata": Amer. Nat., 1890, pp. 530-536.

15. "Die systematische Stellung von Dermochelys, Blains." : Biol. Centralbi., vol. ix (1889), pp. 149-153, 180-191.

16. "Nachträgliche Bemerkungen über die systematische Stellung von Dermochelys, Blainv." : ibid., vol. ix (1889), pp. 617-620.

17. "The Horned Saurians of the Laramie Formation" : Science, vol, xvii (1891), pp. $216,217$.

18. "Remarks on the Reptiles generally called Dinosauria": Amer. Nat., 1891, pp. $434-454$.

19. "On the Relations of Caerttochelys, Ramsay" : ibid., 1891, pp. 631-639.

20. "Notes on some little-known American Fossil Tortoises": Proc. Acad. Nat. Sei. Philad, 1891, pp. 411-430.

21. "On the Morphology of the Skull in the Mosasaurida": Journ. Morph., rol. vii (1892), pp. $1-22$, pls. i, ii.

22. "Bemerkungen über die Osteologie der Schläfengegend der höheren Wirbelthiere": Anat. Anz., vol. x (1894), pp. 315-330.

23. "Die Palatingegend der Ichthyosauria": ibid., vol. x (1894), pp. 456-459.

24. "Cope on the Temporal Part of the Skull, and on the systematic position of the Mosasauridie: A Reply": Amer. Nat., 189., pp. 998-1002.

25. "The Paroccipital of the Squamata and the Affinities of the Mosasaurida once more": ibid., 1896, pp. 143-147, pl. ir.

26. "The Stegocephali": Anat. Anz., vol. xi (1896), pp. 657-673.

27. "Bemerkungen über die Phylogenie der Schildkröten": ibid., vol. xii (1896), pp. $561-570$.

28. [With E. C. Case.] "On the Morphology of the Skull of the Pelycosauria and the Origin of the Mammals" : ibid., vol. xiii (1897), pp. 109-120.

29. "Ceber die systematische Stellung der Microsaurier": ibid., rol. xiv (1897), pp. 148-15i.

30. "Archegosaurus" : Amer. Nat., 1897, pp. 875-980.

\title{
JOHN CARRICK MOORE, M.A., F.R.S., F.G.S.
}

\author{
BORN 1804.
}

Died February 10, 1898.

Bx the death of John Carrick Moore, science loses the last of that band of ardent field-geologists who, during the first half of the present century, did so much to investigate the underground structure of the British Islands. Inspired by the example and animated by the scientific principles of William Smith, they carried out in fuller detail than was possible to their master, his great idea of delineating in maps and sections the distribution and relations of the British strata, guided everywhere by the organic remains which they contain. But while this band of workers-which included such names as those of Buckland, Conybeare, Webster, Mantell, Dixon, Lonsdale, Sedgwick, Murchison, Fitton, De la Beche, Godwin-Austen, and Phillips-were so deeply influenced by the teaching of William Smith, yet they were seldom, with the exception of the last-mentioned, personally instructed by him, but derived their knowledge of his principles and methods at second-hand from men like Richardson, Townsend, and Farey, who were proud to act as the disciples and interpreters of the distinguished "Father of English Geology."

John Carrick Moore came of a famous stock. His grandfather, Dr. John Moore, the friend and biographer of Smollett, was the author of many well-known works, of which the novel "Zeluco" has been longest remembered. Three of the sons of Dr. John Moore 
had very distinguished careers. The eldest surviving son was General Sir John Moore, the hero of Corunna, and a younger son was Admiral Sir Graham Moore, whose exploits on the sea were scarcely less notable than those of his elder brother in the field. The father of John Carrick Moore was James Moore, the second surviving son of Dr. John Moore, who studied medicine in Edinburgh and London, and became one of the most distinguished surgeons of his day. He was the friend of Jenner, and, as a well-known writer in favour of vaccination, was appointed to succeed that surgeon as director of vaccine establishments.

James Moore, who practised extensively for many years in London, was the author of various medical treatises and of a biography of his brother, General Sir John Moore, published in 1833. Having had bequeathed to him by a Mr. Carrick, a banker in Glasgow, the estate of Corsewall, in Wigtownshire, near Stanraer and Port Patrick, James Moore added to his own surname that of Carrick. In 1825 James Carrick Moore retired from practice, and, having built himself an excellent house upon his estate on the shores of Loch Ryan, spent the remainder of his life there, dying in 1834 at the age of 71. On their mother's side, the Moores were descended from Robert Simson, the celebrated geometrician.

John Carrick Moore was the second son of James Carrick Moore, and was born in 1804 . He went to Cambridge, and was educated at Queen's College, proceeding to the degree of M.A., and devoting much attention to mathematics and physics. Before the year 1838, his attention seems to have been attracted by the rocks of the Rhinns of Wigtownshire, near his residence, for we find that he was in communication with Charles Lyell, who identified the fossils found by him as graptolites. In the year named, he was elected a Fellow of the Geological Society.

In 1839 he traced out carefully the succession of strata along the west shore of Loch Ryan, and in the following year a paper on the subject was read by him to the Geological Society. In 1841, Sedgwick, crossing from Ireland, paid a visit to Corsewall, and was accompanied by John Carrick Moore in a tour through Ayrshire. In September, 1843, Lyell and his wife paid a visit to the same hospitable dwelling, examining and confirming the accuracy of Moore's sections. Much of Lyell's time seems to have been spent in studying the rain-and hail-prints, with the fucoid-and crustaceanmarkings on the shores of Loch Ryan, and he subsequently wrote to Moore: "The Loch is a grand magazine of geolngical analogiestidal, littoral, conchological, sedimentary, etc., which I envy you having at your door." Subsequently to this visit, Lyell, under the direction of Moore, visited the remarkable rocks in the neighbourhood of Ballantrae, and bore testimony to the accuracy of his friend's work there.

In 1846 we find John Carrick Moore had become so identified with the work of the Geological Society that he was elected Secretary, and in the same year he became a member of the Geological Society Club. He held the office of Secretary for six years (1846-52), when 
he was elected a Vice-President of the Society (1858-4), resuming his post of Secretary in $180 \tilde{5}$ for one year. So active, indeed, was Carrick Moore in the administration of the Geological Society's affairs, that between 1846 and 1875 we find him absent from the Council only in four years; he was a Vice-President in 1862, and again in 1864-5. In 1848 he read a more extended paper to the Geological Society on the Silurian rocks of the Wigtownshire coast, the fossils being described and figured by Salter. In 1856 and 1858 Moore communicated accounts of further observations on Wigtownshire geology to the Geological Society, while his general interest in geological research was shown by the papers written by him in 1850 and in 1863, on fossils collected and sent home from San Domingo by Mr. Heniker, and from Jamaica by Lucas Barrett. In 1849 we find him describing the Oligocene fossils found in the New Forest.

John Carrick Moore was proposed as a Fellow of the Royal Society in November, 1855, his nomination paper being signed first by his friend Charles Lyell, while others who subscribed from personal knowledge were Sedgwick, Murchison, Hopkins, Leonard Horner, and Faraday. He does not appear, however, to have ever contributed a paper to the Society. By his patient labours in studying the geology of Galloway he made valuable additions to our knowledge of the stratified rocks of Britain, and he took a distinguished place among the band of amateur workers-including many landed proprietors, clergymen, soldiers, and doctors-to whose painstaking and detailed work in the field English geology owes so much. Among these men, John Carrick Moore was always held in the highest esteem, and his time and energy were ungrudgingly devoted alike to the advancement of his favourite science by careful studies in the field, and to the promotion of the interests of the Society identified with that science, during the parts of the year when he resided in London.

In 1864 Andrew Ramsay spent a few days with John Carrick Moore at Corsewall, mapping the peninsula which terminates in Corsewall Point, for the Geological Survey of Scotland. Of John Carrick Moore's wide sympathies with all matters connected with geology, and of the knowledge and ability with which, owing to his early training at Cambridge, he was able to deal with those questions of physical geology demanding an acquaintance with mathematical methods, we have abundant evidence. Between 1865 and 1867 he sent a series of letters to the Philosophical Magazine, dealing in a very able and critical manner with Ramsay's theory of the origin of lake-basins, and with Croll's theory of the cause of the Glacial Period. These letters show that Moore had not forgotten his early training, and had kept himself abreast of the science of the day by his studies of physical questions ; and the substantial justice of his criticisms has been abundantly shown by later researches. In 1875 he wrote to Nature, pointing out a curious oversight of Humboldt in his "Cosmos."

In 1875 John Carrick Moore finally withdrew from the Council of the Geological Society, upon which he had served so long and so 


\section{Miscellaneous-Hereford Earthquale-Ossiferous Caves.}

faithfully; and from that time forward he would seem to have ceased to take any active part in scientific work. Few of the present generation of geologists can even recollect having seen the stately and courteons gentleman, who was at one time so indefatigable in the service of their Society, and who had so frequently acted as one of its officials. For nearly a quarter of a century after this withdrawal from public activity, however, John Carrick Moore lived on, spending his time between his seat in Wigtownshire and the house in Eaton Square, where he died on February 10, 1898, at the great age of 94 . His only son had predeceased him, but a danghter survives, the estate passing to his nephew Colonel Sir David Carrick Buchanan, of Drumpellier. Besides the Corsewall estate, John Carrick Moore owned property in Kirkcudbrightshire and in England, and he was a Deputy-Lieutenant of the county of Wigtownshire. He was not less highly respected among the gentry of his county and the tenants of his estate than in the circles of seientific society in London, in which his presence was so long conspicuous.

J. W. J.'

\section{MISCEIIAINEOUS.}

The Hereford Earthquake of December 17th, 1896.-A report on this important earthquake by Dr. Charles Davison, F.G.S., will be published in the autumn, if a sufficient number of subscriptions be obtained to defray the cost of printing. The work is founded on nearly 3,000 observations made at places distributed over an area of about 100,000 square miles. This area exceeds that disturbed by any other known British earthquake, and includes every county in Fngland but three, the whole of Wales, the Isle of Man, and the eastern counties of Ireland. Copies of the prospectus may be obtained from Messrs. Cornish Bros., 37, New Street, Birmingham.

Ossiferous Caves in the Basque Country (Bayonne). Mr. George Greenwood, Broadhanger, Petersfield, Hants, lately visited the ossiferous caves at Isturitz, Hasparren, in the Basque country (Bayonne), and brought away specimens of the teeth of the Great Cave Bear Ursus spelaus, Horse, and Ibex. The deposits are so rich in mammalian remains that the proprietor is working them for the purpose of selling the deposit for manufacturing bonemanure for the farmers. It is to be regretted that no effort is being made to save the splendid specimens of the Cave Bear and otber animals, as well as remains of primitive man, which these caverns afford. Could not a committee of the British Association under Section $\mathbf{C}$ take the matter up, and obtain a grant to work these interesting caves? Monsieur Roth, of Bayonne, is the only gentleman in the neighbourhood with scientific tastes who might be induced to help in such a good work.-Own Bones.

1 Proceedings of the Royal Society, vol. lxiii. 